University of Nebraska - Lincoln

DigitalCommons@University of Nebraska - Lincoln

Publications from USDA-ARS / UNL Faculty

U.S. Department of Agriculture: Agricultural

Research Service, Lincoln, Nebraska

2013

Switchgrass Biomass Composition Altered by Six Generations of

Divergent Breeding for Digestibility

\author{
Kenneth P. Vogel \\ University of Nebraska-Lincoln, kvogel1@unl.edu \\ R. B. Mitchell \\ USDA-ARS, rob.mitchell@ars.usda.gov
}

G. Sarath

USDA-ARS, Gautam.sarath@ars.usda.gov

H. G. Jung

USDA-ARS

B. S. Dien

USDA-ARS, Bruce.Dien@ars.usda.gov

See next page for additional authors

Follow this and additional works at: https://digitalcommons.unl.edu/usdaarsfacpub

Vogel, Kenneth P.; Mitchell, R. B.; Sarath, G.; Jung, H. G.; Dien, B. S.; and Casler, M. D., "Switchgrass Biomass Composition Altered by Six Generations of Divergent Breeding for Digestibility" (2013).

Publications from USDA-ARS / UNL Faculty. 1950.

https://digitalcommons.unl.edu/usdaarsfacpub/1950

This Article is brought to you for free and open access by the U.S. Department of Agriculture: Agricultural Research Service, Lincoln, Nebraska at DigitalCommons@University of Nebraska - Lincoln. It has been accepted for inclusion in Publications from USDA-ARS / UNL Faculty by an authorized administrator of DigitalCommons@University of Nebraska - Lincoln. 


\section{Authors}

Kenneth P. Vogel, R. B. Mitchell, G. Sarath, H. G. Jung, B. S. Dien, and M. D. Casler 


\title{
Switchgrass Biomass Composition Altered by Six Generations of Divergent Breeding for Digestibility
}

\author{
K. P. Vogel,^ R. B. Mitchell, G. Sarath, H. G. Jung, B. S. Dien, and M. D. Casler
}

\begin{abstract}
Biomass composition of switchgrass (Panicum virgatum L.) can affect its utilization by ruminants and its conversion to liquid fuels in a biorefinery. The objective of this study was to evaluate the effects of six generations of divergent breeding for forage in vitro dry matter digestibility (IVDMD) on switchgrass biomass composition, forage quality traits, and ethanol yield. Initially there was one cycle of selection for both low (C-1) and high IVDMD (C1 = cv. Trailblazer), followed by four additional breeding cycles for high IVDMD. In cycles 4 and 5, winter survival was included as a selection criterion because of decreased winter survival of the C3 population. The experimental populations that were produced by these breeding generations and nine half-sib families from cycle 5 were evaluated for two post-establishment years at the research station in eastern Nebraska, where all the breeding work was conducted. The six breeding generations resulted in significant differences among the populations for all the 28 cell wall and non-cell-wall composition variables measured, forage quality, and ethanol yield traits measured except for total biomass $\mathrm{C}$, cell wall concentration, soluble glucose, and etherified ferulates. These traits included all cell wall and nonstructural carbohydrates. Breeding for the heritable complex trait IVDMD affected a large number of plant biomass characteristics and also adversely affected plant biomass yield and winter survival.
\end{abstract}

K.P. Vogel, R.B. Mitchell, and G. Sarath, USDA-ARS, Grain, Forage, and Bioenergy Res. Unit, 137 Keim Hall, Dep. of Agronomy and Horticulture, Univ. of Nebraska-Lincoln, Lincoln, NE 68583-0937; H.G. Jung, USDA-ARS (retired), Plant Science Research Unit and Dep. Agronomy and Plant Genetics, 411 Borlaug Hall, 1991, Upper Buford Circle, St. Paul, MN 55108-6026; B.S. Dien, USDA-ARS Fermentation Biotechnology Res. Unit, National Center for Agricultural Utilization Res., 1815 N. University Street, Peoria, IL 61604; M.D. Casler, USDA-ARS, U.S. Dairy Forage Res. Center, 1925 Linden Drive West, Madison, WI 53706-1108. Mention of trade names or commercial products in this publication is solely to provide specific information and does not imply recommendations or endorsement by the U.S. Department of Agriculture. The USDA is an equal opportunity employer. Received 18 Sept. 2012. ^Corresponding author (Ken.Vogel@ars.usda.gov).

Abbreviations: ADL, reduced acid detergent lignin; B\&WFS, between-and-within family selection; IVDMD, in vitro dry matter digestibility; MSFS, multi-step family selection; NIRS, near infrared reflectance spectrometry; RRPS, restricted recurrent phenotypic selection; SSF, simultaneous saccharification and fermentation; see Table 2 for an extensive listing of abbreviations for biomass composition or conversion traits.

Cwitchgrass (Panicum virgatum L.) is a native North American $\checkmark$ prairie grass that has been used in the Great Plains and the Midwest of the United States as a warm-season pasture grass for over 70 yr (Vogel, 2004) and, since 1990, has been under development as a biomass energy crop for use on marginal cropland (Vogel et al.,2011; Casler et al., 2012). Forage or biomass quality affects the utilization of grasses by ruminants and also the conversion efficiency of biomass to ethanol via saccharification and fermentation (Vogel et al., 2011; Sarath et al., 2011). In vitro dry matter

Published in Crop Sci. 53:853-862 (2013).

doi: 10.2135/cropsci2012.09.0542

(C) Crop Science Society of America | 5585 Guilford Rd., Madison, WI 53711 USA

All rights reserved. No part of this periodical may be reproduced or transmitted in any form or by any means, electronic or mechanical, including photocopying, recording, or any information storage and retrieval system, without permission in writing from the publisher. Permission for printing and for reprinting the material contained herein has been obtained by the publisher. 
digestibility (IVDMD) is an artificial rumen procedure developed by Tilley and Terry (1963) that measures the digestibility of forage using rumen fluid. The IVDMD test has been demonstrated to be a good indicator of ethanol yield from switchgrass biomass via simultaneous saccharification and fermentation (SSF) (Sarath et al., 2011).

Breeding work to improve the IVDMD of switchgrass was initiated in 1973 with the goal of improving the average daily gains of beef cattle (Bos taurus) grazing switchgrass (Vogel et al., 1981). The first breeding cycle involved divergent selection using a modified restricted recurrent phenotypic selection (RRPS) breeding method (Vogel and Pedersen, 1993) with selection for both increased (high) and decreased (low) IVDMD. Selections were made from two breeding populations, "EY" and "FF," that had been developed by pioneer switchgrass breeder L. C. Newell and were adapted to the central Great Plains and the Midwest. Both populations were similar in maturity and had not undergone any previous breeding work for forage quality traits (Newell and Moline, 1978). Plants were selected from both populations for polycrossing in separate $\mathrm{EY} \times$ FF Low IVDMD and the EY $\times$ FF High IVDMD polycross nurseries (Table 1; Vogel et al., 1981). Both populations were upland, octaploid populations. Because of the cultivar development systems used in switchgrass breeding, cultivars and experimental strains are synthetic populations. The first cycle of divergent selection resulted in significant changes in the IVDMD (Vogel et al., 1981). The divergent populations and the then widely used cultivar Pathfinder were planted in replicated pastures for grazing evaluation by beef yearling heifers and steers. Average daily gains of cattle on the high IVDMD population were significantly greater than the low IVDMD population and Pathfinder (Anderson et al., 1988). The high IVDMD C1 population was released as the cultivar Trailblazer on the basis of the results of the grazing trial (Vogel et al., 1991).

Two additional cycles of breeding for high IVDMD were conducted in the EY $\times$ FF high IVDMD population. Continued breeding progress for improving IVDMD through cycles 2 (C2) and 3 (C3) using modified RRPS was documented by Hopkins et al. (1993). No selection pressure was applied for any trait except for IVDMD, and by the third cycle, forage or biomass yield was reduced (Hopkins et al., 1993). The C4 selection nursery was a RRPS nursery that was established using greenhouse-grown seedlings that had over 1100 plants. Plants were well established and flowered the establishment year. Unexpectedly, almost all the plants in the nursery did not survive the winter of 1986-1987. Adjacent switchgrass selection nurseries with populations of similar adaptation did not have any winter survival problems. The C3 parents of the plants in the C4 selection nursery survived the winter. Seed was harvested from the individual genotypes in the $\mathrm{C} 3$ polycross nursery to produce half-sib family seed and to develop a C3 bulk population. The half-sib family seed was used to establish a between-and-within family selection (B\&WFS) nursery using greenhouse-grown seedlings (Vogel et al., 2002; Vogel and Pedersen, 1993), while the C3 bulk was used to evaluate winter survival in a multilocation seeded spacedplant trial (Casler et al., 2002). In the multilocation study, selection for high IVDMD increased IVDMD, reduced acid detergent lignin (ADL) concentration, reduced biomass yield, and resulted in decreased winter survival (Casler et al., 2002). In the half-sib family selection nursery, there were significant differences among families for IVDMD, biomass yield on a per plant basis, and winter survival (Vogel et al., 2002). Some families had both high IVDMD and good winter survival. On the basis of these results, plants with both high IVDMD and good winter survival were selected from the best families for the same traits to complete the fourth breeding generation (C4). Another B\&WFS breeding cycle (C5) was conducted for the same traits, namely, winter survival and high IVDMD. Including the first generation of breeding for low IVDMD, six generations of divergent breeding for IVDMD were completed in the $\mathrm{EY} \times \mathrm{FF}$ population (Table 1).

It was known from the previous research that the multiple generations for high and low IVDMD changed ADL and forage fiber concentrations (Hopkins et al., 1993; Casler et al., 2002; Vogel et al., 2002), but it was unknown what effect the multibreeding generations had on other biomass composition traits. The development of a set of near infrared reflectance spectrometry (NIRS) calibrations for 28 forage and biomass composition traits of switchgrass has made it economically feasible to conduct comprehensive biomass composition analyses of a large number of samples (Vogel et al., 2010). The objective of this study was to determine the composition, forage quality, and potential ethanol yield changes in switchgrass biomass that resulted from the multiple generations of breeding for differences in biomass IVDMD.

\section{MATERIALS AND METHODS}

\section{Breeding History}

Populations were named NE Trailblazer followed by the selection cycle in which the population was developed to simplify their nomenclature and were abbreviated by using the selection cycle. The breeding history of the NE Trailblazer populations has been described previously for breeding cycles C-1, C0, C1, C2, and C3 (Vogel et al., 1981; Hopkins et al., 1993) and are summarized in Table 1. In brief, a modified form of RRPS was used in which a nursery row of spaced plants was used as the selection unit rather than a square block of plants. The most leafy, vigorous plants in a row (about 20 to 25\%) were sampled at the R1 (panicle emergence) to R2 (panicle fully emerged) stage of maturity for IVDMD analyses. Initially the Tilley and Terry (1963) procedure was used to determine IVDMD, which later was replaced with the filter bag IVDMD method (Vogel et 
Table 1. NE Trailblazer switchgrass (Panicum virgatum L.) populations developed by multiple generations of divergent selection for reduced (low) or increased (high) in vitro dry matter digestibility (IVDMD). RRPS, restricted recurrent phenotypic selection; B\&WFS, between-and-within family selection; MSFS, multi-step family selection.

\begin{tabular}{|c|c|c|}
\hline Population & Previous designation and breeding history & Abbreviation \\
\hline NE Trailblazer C-1 & $\begin{array}{l}\text { EY } \times \text { FF low IVDMD C-1. One cycle of breeding for reduced IVDMD using modified RRPS. } \\
\text { Based on } 13 \mathrm{EY} \text { and } 12 \mathrm{FF} \text { plants (Vogel et al., 1981). }\end{array}$ & C-1 \\
\hline NE Trailblazer CO & $\begin{array}{l}\text { EY } \times \text { FF synthesized base population. Produced by polycrossing } 150 \text { random plants from } \\
\text { each population. Advanced to the Syn } 2 \text { generation. }\end{array}$ & $\mathrm{CO}$ \\
\hline Trailblazer & $\begin{array}{l}\text { EY } \times \text { FF C1, cultivar developed by } 1 \text { cycle of breeding for increased IVDMD. Based on } 13 \\
\text { EY and } 12 \text { FF plants (Vogel et al., 1981). }\end{array}$ & C1 \\
\hline NE Trailblazer C2 & $\begin{array}{l}\text { EY } \times \text { FF C2, developed by } 2 \text { cycles of RRPS breeding for increased IVDMD (Hopkins et al., } \\
\text { 1993). Based on } 88 \text { selected plants. }\end{array}$ & $\mathrm{C} 2$ \\
\hline NE Trailblazer C3 & $\begin{array}{l}\text { EY } \times \text { FF C3, developed by } 3 \text { cycles of RRPS breeding for increased IVDMD (Hopkins et al., } \\
\text { 1993). Based on } 48 \text { selected plants. }\end{array}$ & C3 \\
\hline NE Trailblazer C4 & $\begin{array}{l}\text { EY } \times \text { FF C4 strain developed from the C3 population by B\&WFS on } 48 \text { half-sib families for } \\
\text { increased IVDMD and winter survival. Based on } 49 \text { selected plants. }\end{array}$ & C4 \\
\hline NE Trailblazer C5 & $\begin{array}{l}\text { EY } \times \text { FF C5 strain developed from the C4 population by B\&WFS on } 49 \text { C4 families for } \\
\text { increased IVDMD and winter survival. Based on } 10 \text { selected plants. }\end{array}$ & C5 \\
\hline NE Trailblazer C4 MSFS & $\begin{array}{l}\text { Population based on six C4 parents reselected on the basis of the IVDMD and survival of } \\
\text { their progeny in the C5 selection nursery. }\end{array}$ & C4 MSFS \\
\hline NE Trailblazer C5 half-sib families & C5 Half-sib families grown in the C6 selection nursery. Nine surviving families. & Genotype numbers \\
\hline
\end{tabular}

al., 1999). The plants with the largest (high) IVDMD values in each row were selected, and two ramets or clonal pieces from the selected plants were transplanted into isolated polycross nurseries using a completely randomized experimental design. Seed was harvested from the individual plants, bulked by genotype, and then an equal amount of seed from each genotype was combined to produce a bulk seed lot that was used to plant seedlings in the greenhouse for the next cycle of breeding or to plant sward or seed increase nurseries.

The B\&WFS breeding method (Vogel and Pedersen, 1993) was used to develop the NE Trailblazer C4 and C5 populations. The C4 selection nursery design has been described in detail by Vogel et al. (2002). Replicated half-sib family plots of eight seedlings were transplanted in the spring of 1991 on 1.1-m centers within and between rows using seed from the 48 genotypes selected in C3. The nursery was harvested in early August of 1993 and 1995 for biomass yield on a plot basis after plants had headed. The nursery was also harvested in 1992 and 1994, but yields were not recorded. Biomass samples were collected for analysis at the time of biomass harvest. The multiyear evaluation period was used to obtain measurements of winter survival over a five-year time period. The number of surviving plants was determined at the time of harvest. A plant was scored as surviving if it had any green harvestable tissue at the time of harvest. Forage yield per plot was converted to yield per plant by dividing plot yield by the number of surviving plants at the time of harvest, which was the first or second week of August. Plants from seven families were selected for polycrossing in 1996. The selected families had survival percentages that were greater than the mean survival percentage of all the families and had IVDMD values that were 15 $\mathrm{mg} \mathrm{g}^{-1}$ greater than that for the Trailblazer check. The number of plants selected per family ranged from 3 to 13 . The plants within families were selected on the basis of a visual assessment for vigor in 1995. A total of 49 plants were selected for polycrossing to produce C4 seed. Seed was harvested from individual plants in 1997, subsampled for seed to be used to start the C5 half-sib family selection nursery, and the remaining seed was bulked. The cycle 5 (C5) breeding nursery was conducted using similar procedures, except each half-sib family plot had 10 plants. It was established in 1998 and harvested on a family plot basis in 1999 and 2000. Selected plants were subdivided into ramets and transplanted into a polycross nursery in the spring of 2003. Seed was harvested from individual plants, bulked by genotype to produce half-sib families, and then bulked using seed from all genotypes in the polycross nursery to produce a C5 bulk population.

Another population was developed by using the multi-step family selection (MSFS) method proposed by Vogel and Pedersen (1993). The cycle 4 polycross nursery had been maintained while the C5 selection nursery was being evaluated. From the results of the C5 selection nursery, six of the 49 genotypes in the C4 polycross nursery were selected on the basis of the high IVDMD and survival of their half-sib families in the C5 selection nursery. Two ramets of these six genotypes were dug from the C4 polycross nursery and moved to a different polycross nursery to establish the C4 MSFS polycross. Seed was harvested in 2004 and 2005 and an equal amount of seed was bulked from each genotype to form the NE Trailblazer C4 MSFS population.

All breeding and evaluation trials were conducted at the University of Nebraska's Agricultural Research and Development Center (ARDC), which is located $50 \mathrm{~km}$ west of Omaha, NE. In the breeding and polycross nurseries, individual plants were transplanted on 1.1-m centers in rows. In the B\&WFS nurseries, family plots were single rows of plants as indicated previously. Herbicides, rototilling, and hand weeding were used for weed control. After the establishment year, the nurseries were fertilized annually in the spring with a single application of $110 \mathrm{~kg} \mathrm{ha}^{-1} \mathrm{~N}$. Each spring, the between-row and withinrow spaces between plants in the nurseries were rototilled with a tractor-mounted rototiller, so that each plant occupied a $0.2-$ $\mathrm{m}^{2}$ mini-sward area at the start of each growing season. Nurseries were harvested in early August of each year after panicle emergence (R2 stage). Biomass samples for quality analyses were collected with hand sickles with a cutting height of $10 \mathrm{~cm}$ before biomass yield harvests. For individual plant evaluation, 4 to 5 tillers were collected per plant while for family plot evaluations, 1 or 2 tillers were collected from each plant in a family plot. No biomass yields were harvested in the RRPS breeding cycles. In the B\&WFS breeding cycles, biomass was harvested 
with a flail-type plot harvester with a cutting height of $10 \mathrm{~cm}$ after biomass quality samples were collected. The biomass quality samples were used to determine dry weight by drying them in a convection oven for $48 \mathrm{~h}$ at $50^{\circ} \mathrm{C}$. The dry matter (DM) concentration was used to determine dry weight yields per plant. Sample dry weights were added to harvested plant or plot weights. Half-sib family plot dry weight yields were converted to biomass yields per plant by dividing plot yield by the number of surviving plants per plot. This was done because not all seedlings in transplanted plots survived the establishment year nor survived all subsequent evaluation years. Yield expressed on a surviving and harvestable plant basis provided an estimate of biomass yield per se by removing the effect of winter-killed plants on family plot yields.

\section{Breeding Generation Evaluation Trial}

A space-transplanted evaluation trial of the populations developed by the six breeding generations was established in the spring of 2006 using greenhouse-grown seedlings from each of the populations and nine half-sib families produced from the selected C5 polycrossed plants. Seed was obtained for only nine half-sib families because of the death of one genotype in the C5 polycross nursery. The space-plant nursery consisted of population or family plots with 10 plants per plot. The plant spacing with plants on 1.1-m centers and nursery management was the same as that used in the B\&WFS selection nurseries. The experimental design was a randomized complete block with six replicates. The nursery was harvested in 2007 and 2008 at the R1 and R2 stages of maturity (Moore et al., 1991), respectively, for biomass quality and yield. In the spring of 2009, the survival percentage of each individual plant in the nursery was visually estimated as the percentage of the crown of the plant from which new growth had emerged.

Switchgrass samples from the plot were dried in a $50^{\circ} \mathrm{C}$ oven for $48 \mathrm{~h}$ to determine DM concentration and then were ground through a $2-\mathrm{mm}$ screen in a Wiley mill and reground in a cyclonetype mill to pass a 1-mm screen. Ground samples were scanned using a Model 6500 near-infrared spectrometer (NIRSystems; now FOSS NIRSystems, Inc.) to determine feedstock composition and conversion. A comprehensive set of switchgrass NIRS prediction equations were used to determine the concentration of biomass composition components (Table 2) of the harvested biomass samples as described by Vogel et al. (2010). The calibrations were based on a calibration set of switchgrass samples that represented a wide range of plant maturities, cultivars, ecotypes, fertility rates, and environments. The NIRS calibration set included prediction of ethanol yield from biomass cellulose following pretreatment and SSF using commercial cellulases and Saccharomyces cerevisiae, which only ferments hexose sugars to ethanol (Dien et al., 2006; Vogel et al., 2010). The Global H statistic (Mahalanobis distance) was used to compare the spectral profiles of the samples from this study with the samples used to develop the NIRS calibrations. Near-infrared spectrometer calibrations are considered to be fully valid for composition estimation when Global $\mathrm{H}$ values are less than 3 (Murray and Cowe, 2004; Shenk and Westerhaus, 1991). All biomass samples had Global $H$ values less than 2.5 for both years, indicating that the samples in the calibration set were fully representative of the biomass samples from this study.

The experimental data from the study was initially analyzed using a randomized complete block, split-plot in time analyses of variance (ANOVA) using Proc GLM of PC-SAS (SAS Institute, 2008). Years and replicates were considered random effects, and the populations and half-sib family treatments were fixed effects. The data set was balanced. The genotype $\times$ year $(G \times Y)$ interaction effect was not statistically significant for most traits, so plot means over years were used in the subsequent analyses, which was a randomized complete block ANOVA using Proc GLM of PC-SAS. Plant survival percentages were analyzed using data only from the spring of 2009.

\section{RESULTS}

There were significant differences among the populations developed by the six generations of divergent breeding for IVDMD for all traits except for total biomass C, cell wall concentration, soluble glucose, and etherified ferulates (Table 3). The changes produced by the long-term breeding work are presented below for each individual trait.

Biomass yield: Single trait selection for increased IVDMD resulted in a $10 \%$ decrease in forage or biomass yield from $\mathrm{C} 0$ through $\mathrm{C} 3$ (Table 3). After C4, when selection pressure was applied for winter survival, population yields remained stable and did not change with breeding cycle. Among the C5 families, one family, 34504, had yields equivalent to the base population and two other families, 12101 and 30901, had yields equivalent to Trailblazer (C1).

IVDMD: Biomass digestibility increased by $40 \mathrm{mg}$ $\mathrm{g}^{-1}$ for $\mathrm{C} 0$ through C3 but decreased after C4 when selection pressure was applied for winter survival. There was significant variation among the C5 half-sib families for IVDMD. Two families, 29705 and 29708, had the largest IVDMD values of any strain in the trial and all but two families had greater IVDMD values than Trailblazer.

Winter survival: In this study winter survival decreased by $10 \%$ from C0 through C3 but improved or remained stable after selection pressure was applied for winter survival in $\mathrm{C} 4$. The $\mathrm{C} 0$ population had significantly greater winter survival than the $\mathrm{C} 2, \mathrm{C} 3, \mathrm{C} 4$, and $\mathrm{C} 5$ populations. There was considerable variation among the half-sib progeny for winter survival, with their range of values exceeding the range of values among the populations developed in the breeding cycles.

NE stage or maturity: There was minimal variation for plant maturity at harvest as determined by the NE (Nebraska) plant staging system (Moore et al., 1991) among the populations developed by the breeding generations. There were significant differences among some of the C5 half-sib families.

Neutral detergent fiber (NDF): NDF decreased with selection for increased IVDMD to C3. The decrease $(8$ $\mathrm{mg} \mathrm{g}^{-1}$ ) was small but significant. Once selection pressure was applied for winter survival (C4), NDF increased in C4 but decreased in C5. The C5 NDF concentration was numerically greater than for $\mathrm{C} 3$ but the difference was not statistically significant. There were significant differences among the C5 half-sib families for NDF, with one family 
having a smaller NDF value than the C3 population. All half-sib families had smaller NDF values than Trailblazer.

Acid detergent fiber (ADF): The response to selection for increased IVDMD on ADF was similar to that for NDF. The decrease in ADF from C0 to C3 was $14.4 \mathrm{mg}$ $\mathrm{g}^{-1}$. The C-1 population had the largest ADF value, while the $\mathrm{C} 3$ population had the smallest value. The range in ADF values among the C5 half-sib families was similar to that between Trailblazer (C1) and C3.

Acid detergent lignin (ADL): ADL increased with selection for low IVDMD and decreased with selection for high IVDMD to C3. The ADL for the C3 population was $17 \%$ smaller than the ADL of the C-1 population. After selection pressure was applied for winter survival in $\mathrm{C} 4$, ADL concentration in the biomass increased. All C5 halfsib families had smaller ADL values than $\mathrm{C} 0$ and ranged from $47.4 \mathrm{mg} \mathrm{g}^{-1}$ for family 30901 to $43.6 \mathrm{mg} \mathrm{g}^{-1}$ for family 10504. The range in ADL values among the families was similar to the range between $\mathrm{C} 1$ and $\mathrm{C} 3$

Klason lignin (KL): KL values were approximately $3 \mathrm{X}$ those of ADL. The response of Klason lignin to selection for IVDMD differed from the response of ADL. The $\mathrm{KL}$ concentration in the $\mathrm{C}-1$ biomass was greater than that in the $\mathrm{C} 0$ population (172.6 vs. $163.8 \mathrm{mg} \mathrm{g}^{-1}$ ), but the $\mathrm{KL}$ concentration in the biomass of $\mathrm{C} 1, \mathrm{C} 2$, and $\mathrm{C} 3$ populations were not statistically different from $\mathrm{C} 0$. The C4 MSFS population had greater KL concentration in its biomass than all other populations except for C-1. The range in KL concentration among the C5 half-sib progeny was equivalent to the entire range among the populations from C-1 to C5. These results indicate that Klason lignin responded differently to selection for IVDMD than did ADL. The correlation between Klason lignin and ADL was $r=0.35(P \leq 0.01)$.

Total biomass C (C): Total C concentration was not statistically different among any of the breeding populations or half-sib families (Table 1). This indicates that the breeding work for IVDMD affected the distribution of $\mathrm{C}$ among the biomass constituents but did not affect total biomass C. Total C ranged from 434.4 to $436.6 \mathrm{mg} \mathrm{g}^{-1}$.

Nitrogen $(\mathrm{N})$ : Biomass $\mathrm{N}$ concentration increased a small amount with each cycle of selection for IVDMD, although the amount of increase between cycles was not always statistically significant. The largest increase in $\mathrm{N}$ concentration occurred between $\mathrm{C} 1$ and C2. All of the C5 half-sib families had greater biomass $\mathrm{N}$ concentrations than the $\mathrm{C} 0$ population, and three families had larger biomass $\mathrm{N}$ concentrations than the breeding populations. Total $\mathrm{N}$ in $\mathrm{C} 0$ was $13.6 \mathrm{mg} \mathrm{g}^{-1}$, while for C5 it was $14.7 \mathrm{mg} \mathrm{g}^{-1}$.

Ash: The response of ash concentration to selection for IVDMD was not consistent. The single cycle of selection for decreased IVDMD increased ash concentration in C-1. Selection for increased IVDMD resulted in no significant change in biomass ash concentration between $\mathrm{C} 0$ and $\mathrm{C} 1$,
Table 2. Biomass composition variables, ethanol yield, and forage quality traits and their abbreviations that were determined on biomass samples from switchgrass (Panicum virgatum L.) populations divergently bred for in vitro dry matter digestibility.

\begin{tabular}{|c|c|}
\hline Variable & Abbreviation \\
\hline \multicolumn{2}{|l|}{ Composition variables } \\
\hline Dry matter & DM \\
\hline Carbon & C \\
\hline Nitrogen & $\mathrm{N}$ \\
\hline Extracted fat & EE \\
\hline Minerals (total ash) & $\mathrm{ASH}$ \\
\hline Klason lignin & $\mathrm{KL}$ \\
\hline Uronic acids ${ }^{\dagger}$ & UA \\
\hline Rhamnose $^{\dagger}$ & $\mathrm{RHA}$ \\
\hline Fucose $^{\dagger}$ & FUC \\
\hline Arabinose $^{\dagger}$ & ARA \\
\hline Xylose $^{\dagger}$ & $X Y L$ \\
\hline Mannose $^{\dagger}$ & MAN \\
\hline Galactose $^{\dagger}$ & GAL \\
\hline Glucose $^{\dagger}$ & GLC \\
\hline$p$-Coumarate esters & PCA \\
\hline Esterified ferulates & FEST \\
\hline Etherified ferulates & FETH \\
\hline Cell wall concentration ${ }^{\ddagger}$ & CWC \\
\hline Sucrose & SUC \\
\hline Soluble glucose & GLCS \\
\hline Fructose & $\mathrm{FRU}$ \\
\hline Total soluble carbohydrates & SC \\
\hline Starch & STA \\
\hline Nonstructural carbohydrates (Starch + SC) & NSC \\
\hline Ethanol/g dry forage & $\mathrm{ETOH}$ \\
\hline \multicolumn{2}{|l|}{ Forage quality composition } \\
\hline Neutral detergent fiber & NDF \\
\hline Acid detergent fiber & ADF \\
\hline Acid detergent lignin & ADL \\
\hline In vitro dry matter digestibility & IVDMD \\
\hline
\end{tabular}

${ }^{\dagger}$ Cell wall carbohydrates.

${ }^{\ddagger}$ Cell wall concentration $=\mathrm{KL}+\mathrm{UA}+\mathrm{RHA}+\mathrm{FUC}+\mathrm{ARA}+\mathrm{XYL}+\mathrm{MAN}+\mathrm{GAL}+$ $\mathrm{GLC}+\mathrm{PCA}+\mathrm{FEST}+\mathrm{FETH}$.

followed by a significant increase between $\mathrm{C} 1$ and $\mathrm{C} 2$, no change between $\mathrm{C} 2$ and 3, and then a significant decrease between $\mathrm{C} 3$ and $\mathrm{C} 4$ when selection for winter survival was instituted, followed by an increase in biomass ash concentration in both the MSFS C4 and the C5 populations. There were significant differences among the half-sib families for biomass ash concentration and all but three of the C 5 families had greater ash concentration than the $\mathrm{C} 0$ population. Ash content of the C5 families ranged from 85.9 to $93.4 \mathrm{mg} \mathrm{g}^{-1}$.

Cell wall concentration (CWC): Cell wall concentration is a calculated variable that is based on the concentration of 12 other biomass constituents. The mean CWC was $722 \mathrm{mg} \mathrm{g}^{-1}$, and there were no statistically significant differences among population and family means for CWC. The correlation between NDF and CWC was $r=$ $0.45(P \leq 0.05)$. 
Table 3. Means for biomass yield, survival, forage quality, and biomass composition traits for switchgrass (Panicum virgatum L.) populations developed by six cycles of divergent selection in switchgrass for in vitro dry matter digestibility (IVDMD) and for half-sib families from the cycle 6 high IVDMD selection nursery. See Table 2 for abbreviations for biomass composition or conversion traits.

\begin{tabular}{|c|c|c|c|c|c|c|c|c|c|c|c|c|c|c|c|c|}
\hline Cycle or family & Yield & Surv. & NE Stage & IVDMD & NDF & ADF & ADL & $\mathrm{KL}$ & $\mathrm{C}$ & $\mathrm{N}$ & Ash & CWC & NSC & EE & STA & SC \\
\hline & $\mathrm{kg} /$ plant & $\%$ & & & & & & & & $-m g / g-$ & & & & & & \\
\hline C-1 & 0.74 & 66 & 3.19 & 591.1 & 730.0 & 414.5 & 52.9 & 172.6 & 435.8 & 13.7 & 90.17 & 720.1 & 26.6 & 12.1 & 4.8 & 21.8 \\
\hline $\mathrm{CO}$ & 0.74 & 69 & 3.20 & 604.5 & 732.1 & 413.2 & 49.3 & 163.8 & 436.6 & 13.6 & 85.47 & 719.5 & 29.7 & 12.0 & 4.7 & 25.0 \\
\hline Trailblazer C1 & 0.68 & 67 & 3.18 & 623.2 & 729.2 & 404.9 & 47.6 & 160.0 & 436.5 & 13.8 & 84.37 & 715.6 & 32.1 & 11.8 & 5.1 & 27.0 \\
\hline C2 & 0.65 & 58 & 3.20 & 641.3 & 724.5 & 402.4 & 44.4 & 162.3 & 434.9 & 14.2 & 88.17 & 712.8 & 31.5 & 11.5 & 4.7 & 26.8 \\
\hline C3 & 0.67 & 59 & 3.19 & 647.9 & 724.0 & 398.8 & 44.1 & 163.2 & 434.4 & 14.5 & 88.0 & 712.5 & 32.9 & 11.3 & 4.5 & 28.4 \\
\hline C4 & 0.68 & 63 & 3.20 & 637.2 & 733.7 & 406.2 & 44.9 & 165.1 & 436.8 & 14.6 & 82.57 & 725.5 & 30.7 & 11.5 & 2.5 & 28.2 \\
\hline C4 MSFS & 0.66 & 65 & 3.18 & 630.0 & 733.0 & 407.9 & 46.6 & 169.8 & 435.7 & 14.6 & 86.27 & 728.8 & 28.6 & 11.8 & 3.2 & 25.5 \\
\hline C5 & 0.68 & 61 & 3.20 & 632.9 & 726.2 & 405.0 & 47.0 & 165.6 & 435.3 & 14.7 & 86.97 & 720.1 & 30.6 & 12.6 & 3.6 & 27.0 \\
\hline \multicolumn{17}{|l|}{ C5 Half-sib families } \\
\hline 10503 & 0.64 & 57 & 3.20 & 649.2 & 722.5 & 400.3 & 45.0 & 168.6 & 434.4 & 15.1 & 93.47 & 721.4 & 27.6 & 12.2 & 3.6 & 24.0 \\
\hline 10504 & 0.65 & 62 & 3.18 & 644.4 & 715.3 & 395.8 & 43.6 & 164.6 & 434.5 & 14.7 & 92.07 & 715.4 & 31.2 & 12.7 & 4.5 & 26.7 \\
\hline 12101 & 0.68 & 67 & 3.20 & 637.1 & 728.1 & 404.1 & 45.7 & 172.9 & 434.4 & 15.0 & 91.9 & 731.0 & 28.6 & 12.1 & 4.0 & 24.6 \\
\hline 29705 & 0.61 & 62 & 3.20 & 654.3 & 721.8 & 396.4 & 43.6 & 162.8 & 434.6 & 15.3 & 90.2 & 719.3 & 28.9 & 11.9 & 3.1 & 25.8 \\
\hline 29708 & 0.60 & 59 & 3.17 & 654.2 & 723.9 & 398.3 & 43.9 & 169.6 & 436.0 & 15.6 & 88.87 & 726.9 & 28.3 & 12.2 & 3.3 & 25.0 \\
\hline 30901 & 0.69 & 59 & 3.20 & 632.8 & 727.8 & 409.8 & 47.4 & 168.8 & 435.3 & 14.7 & 90.17 & 722.6 & 29.8 & 12.4 & 3.7 & 26.1 \\
\hline 34102 & 0.66 & 68 & 3.20 & 629.1 & 722.7 & 400.0 & 46.9 & 173.5 & 436.6 & 14.6 & 87.87 & 730.1 & 29.4 & 13.3 & 3.6 & 25.9 \\
\hline 34106 & 0.66 & 66 & 3.21 & 641.2 & 726.6 & 400.5 & 44.3 & 170.9 & 435.4 & 14.6 & 87.17 & 723.1 & 30.3 & 12.2 & 4.2 & 26.1 \\
\hline 34504 & 0.76 & 71 & 3.20 & 643.8 & 727.6 & 402.7 & 44.8 & 160.9 & 435.8 & 14.2 & 85.97 & 724.9 & 32.2 & 12.2 & 4.1 & 28.1 \\
\hline Mean & 0.67 & 63 & 3.19 & 635.0 & 726.0 & 404.0 & 46.0 & 167.0 & 435.0 & 14.6 & 88.07 & 722.0 & 29.9 & 12.0 & 4.0 & 26.0 \\
\hline s & 0.08 & 5 & 0.02 & 13.0 & 6.5 & 7.0 & 2.2 & 7.7 & 1.7 & 0.6 & 3.7 & 10.7 & 2.9 & 0.7 & 1.0 & 2.6 \\
\hline F ratio & $1.9^{*}$ & $3.6^{\star \star}$ & $2.9^{\star \star}$ & $9.4^{* *}$ & $3.0^{\star *}$ & * $3.7^{\star *}$ & * $7.0^{* \star}$ & $1.9^{*}$ & $1.4 n s^{\dagger}$ & $5.53^{*}$ & $3.5^{\star *}$ & $1.7 \mathrm{~ns}$ & $2.2^{*}$ & $2.8^{* *}$ & $3.3^{\star \star}$ & $2.4^{\star *}$ \\
\hline \multirow[t]{2}{*}{ LSD 0.05} & 0.06 & 4 & 0.02 & 10.6 & 5.3 & 5.7 & 1.8 & 6.3 & $1.4 \mathrm{~ns}$ & 0.4 & 3.0 & $8.7 \mathrm{~ns}$ & 2.3 & 0.6 & 0.8 & 2.1 \\
\hline & ARA & $X Y L$ & MAN & GAL & GLC & SUC & GLCS & FRU & RHA & FUC & UA & PCA & FETH & FEST & ETOH & \\
\hline C-1 & 29.5 & 197.1 & 6.2 & 7.8 & 281.2 & 15.9 & 4.0 & 1.9 & 1.00 & 0.15 & 16.9 & 5.70 & 0.42 & 1.42 & 79.4 & \\
\hline CO & 30.0 & 201.6 & 5.9 & 8.1 & 284.3 & 17.8 & 4.3 & 2.9 & 1.02 & 0.14 & 16.9 & 5.88 & 0.58 & 1.52 & 83.0 & \\
\hline Trailblazer C1 & 30.4 & 200.7 & 6.2 & 8.0 & 284.0 & 19.7 & 4.6 & 2.7 & 0.98 & 0.13 & 17.0 & 5.99 & 0.49 & 1.64 & 86.3 & \\
\hline C2 & 30.4 & 197.1 & 6.1 & 8.1 & 282.4 & 18.4 & 4.8 & 3.6 & 1.02 & 0.12 & 17.3 & 5.84 & 0.40 & 1.57 & 87.0 & \\
\hline C3 & 30.6 & 195.2 & 6.1 & 8.2 & 283.1 & 19.9 & 4.6 & 3.8 & 1.03 & 0.12 & 17.4 & 5.75 & 0.39 & 1.57 & 89.5 & \\
\hline C4 & 30.4 & 200.5 & 6.3 & 8.0 & 288.3 & 20.0 & 4.6 & 3.6 & 0.97 & 0.13 & 17.3 & 6.32 & 0.48 & 1.79 & 87.1 & \\
\hline C4 MSFS & 30.7 & 200.1 & 6.0 & 8.2 & 287.7 & 18.2 & 4.3 & 2.9 & 1.01 & 0.13 & 17.2 & 5.84 & 0.47 & 1.60 & 86.7 & \\
\hline C5 & 30.5 & 198.0 & 6.1 & 8.1 & 285.4 & 19.5 & 4.5 & 2.9 & 0.99 & 0.11 & 17.4 & 5.87 & 0.43 & 1.64 & 86.8 & \\
\hline \multicolumn{17}{|l|}{ C5 Half-sib families } \\
\hline 10503 & 31.0 & 195.8 & 6.5 & 8.3 & 284.6 & 17.2 & 4.1 & 2.7 & 1.06 & 0.11 & 17.6 & 5.70 & 0.43 & 1.65 & 87.7 & \\
\hline 10504 & 31.4 & 195.3 & 6.6 & 8.5 & 282.3 & 19.0 & 4.4 & 3.3 & 1.08 & 0.11 & 17.6 & 5.75 & 0.43 & 1.64 & 88.8 & \\
\hline 12101 & 30.8 & 199.0 & 6.1 & 8.1 & 287.7 & 17.6 & 4.3 & 2.7 & 0.99 & 0.12 & 17.4 & 5.82 & 0.47 & 1.62 & 87.5 & \\
\hline 29705 & 31.2 & 199.3 & 6.4 & 8.3 & 285.0 & 19.0 & 4.1 & 2.7 & 1.00 & 0.11 & 17.4 & 5.77 & 0.38 & 1.69 & 89.8 & \\
\hline 29708 & 31.8 & 197.7 & 6.8 & 8.5 & 285.7 & 18.3 & 3.9 & 2.8 & 1.11 & 0.09 & 17.7 & 5.78 & 0.43 & 1.64 & 89.0 & \\
\hline 30901 & 30.2 & 195.3 & 6.3 & 8.0 & 287.2 & 18.6 & 4.5 & 3.0 & 0.99 & 0.12 & 17.5 & 5.99 & 0.45 & 1.65 & 85.5 & \\
\hline 34102 & 31.1 & 201.2 & 6.3 & 8.2 & 283.6 & 19.1 & 4.3 & 2.5 & 0.99 & 0.12 & 17.2 & 5.69 & 0.43 & 1.60 & 85.3 & \\
\hline 34106 & 30.4 & 197.2 & 5.9 & 8.1 & 284.4 & 18.9 & 4.2 & 3.0 & 1.01 & 0.13 & 17.2 & 5.79 & 0.43 & 1.57 & 86.7 & \\
\hline 34504 & 31.2 & 201.9 & 6.1 & 8.3 & 289.7 & 20.7 & 4.3 & 3.1 & 0.96 & 0.12 & 17.2 & 6.14 & 0.49 & 1.79 & 89.4 & \\
\hline Mean & 30.7 & 198.0 & 6.2 & 8.2 & 285.1 & 18.7 & 4.3 & 3.0 & 1.01 & 0.12 & 17.0 & 5.86 & 0.45 & 1.62 & 86.8 & \\
\hline s & 0.6 & 3.0 & 0.4 & 0.3 & 3.7 & 1.6 & 0.7 & 0.7 & 0.07 & 0.01 & 0.3 & 0.25 & 0.11 & 0.10 & 2.4 & \\
\hline F ratio & $4.5^{\star \star}$ & $3.5^{\star \star}$ & $2.9^{\star \star}$ & $2.0^{*}$ & $2.4^{\star *}$ & $3.1^{\star *}$ & $0.7 n s$ & $2.7^{\star \star}$ & $2.0^{\star}$ & $5.7^{\star \star}$ & $4.2^{\star *}$ & $2.6^{\star \star}$ & $1.1 \mathrm{~ns}$ & $4.7^{\star *}$ & $7.1^{\star *}$ & \\
\hline LSD 0.05 & 0.5 & 2.5 & 0.3 & 0.3 & 3.0 & 1.3 & $0.6 n s$ & 0.6 & 0.05 & 0.01 & 0.2 & 0.20 & $0.09 \mathrm{~ns}$ & 0.08 & 1.9 & \\
\hline
\end{tabular}

*Indicates significance at the 0.05 level of probability.

${ }^{\star \star}$ Indicates significance at the 0.01 level of probability.

†ns, no significant differences. Fisher's protected LSD values are labeled as "ns" if the $F$ test was not significant. 
Nonstructural carbohydrates (NSC): Nonstructural carbohydrates consist of biomass starch and total soluble carbohydrates. Selection for reduced IVDMD resulted in a significant decrease in C-1 NSC concentration. Selection for increased IVDMD resulted in a significant increase in biomass NSC concentration between $\mathrm{C} 0$ and $\mathrm{C} 1$, no significant response between $\mathrm{C} 1$ and $\mathrm{C} 2$ or $\mathrm{C} 3$, and then a reduction in NSC when selection pressure for winter survival was applied in $\mathrm{C} 4$ and $\mathrm{C} 5$, with the biggest reduction occurring in one cycle of MSFS. The range in NSC among the C5 half sib families (27.6 to $32.2 \mathrm{mg}$ g-1) was equivalent to the range among the populations produced by the multigenerations of breeding.

Extracted fat (EE): The range in EE concentration among experimental strains and half sib families (11.3 to $13.3 \mathrm{mg} \mathrm{g}^{-1}$ ) was small, but there were significant differences. Biomass-extracted fat concentration decreased steadily with each selection cycle for high IVDMD to C3, which had significantly less EE than C0. When selection for winter hardiness was included as a selection criterion, EE concentration increased and the C5 EE concentration was significantly greater than the EE concentration of $\mathrm{C} 0$. All but one of the C5 half-sib families, 29705, had EE concentrations that were numerically larger than C0 EE concentration, and all the families had EE concentrations that were significantly greater than $\mathrm{C} 3$ biomass $\mathrm{EE}$ concentration.

Starch (STA): Populations C-1, C0, C1, C2, and C3 did not differ for STA concentration. The populations developed from C3 by including winter survival as a co-selection variable had significantly smaller STA concentrations than the previous populations. The largest change was between C3 and C4. All but one of the C5 half-sib families, 10504, had significantly less STA concentration than Trailblazer, and five of the families had less STA concentration than C0. The range in STA concentration was 2.5 to $5.1 \mathrm{mg} \mathrm{g}^{-1}$.

Total soluble carbohydrates (SC): The single cycle of selection for reduced IVDMD resulted in a $13 \%$ reduction in SC. Selection for increased IVDMD resulted in an equivalent significant increase in SC between $\mathrm{C} 0$ and $\mathrm{C} 3$. After selection pressure was applied for winter survival, $\mathrm{SC}$ began to decline in concentration, and there was a significant reduction in SC between C3 and C4 MSFS.

Arabinose (ARA): Arabinose and xylose are cell-wallassociated pentoses. Mean arabinose concentration was in much lower concentration than xylose (30.7 vs. $198.0 \mathrm{mg}$ $\mathrm{g}^{-1}$ ) in the switchgrass biomass (Table 3). By C3, selection for increased IVDMD had increased ARA concentration by a small but significant amount, and the single cycle of selection for reduced IVDMD also reduced ARA concentration. There were no significant changes among populations following C3 when selection pressure was applied for winter survival.

Xylose (XYL): Selection for increased IVDMD resulted in a decrease of $6.4 \mathrm{mg} \mathrm{g}^{-1}$ in XYL between C0 and C3. After selection pressure was applied for winter survival, in C4 and following cycles XYL concentration increased. All the C5 half-sib families had equivalent or greater XYL concentrations than C3.

Mannose (MAN): Mannose had the lowest concentration of the cell wall polysaccharide sugar components. There were significant differences among the populations and half-sib families, but differences were very small. The range in mannose concentration was $0.7 \mathrm{mg} \mathrm{g}^{-1}$.

Galactose (GAL): There were differences in galactose concentrations among the populations and C5 halfsib families, but the differences again were small, with a range value of $0.7 \mathrm{mg} \mathrm{g}^{-1}$. The $\mathrm{C} 3$ population had significantly higher galactose concentration in its biomass than the $\mathrm{C}-1$ population.

Glucose (GLC): Cell wall glucose is produced by the acid catalyzed saccharification of cell wall cellulose, and it had the greatest mean concentration $\left(285.1 \mathrm{mg} \mathrm{g}^{-1}\right)$ of the cell wall polysaccharide components. A single cycle of selection for reduced IVDMD resulted in a small $(3.1 \mathrm{mg}$ $\mathrm{g}^{-1}$ ) but significant decrease in GLC concentration. Selection for increased IVDMD did not result in any significant changes in GLC concentration until C4. Both the C4 and C4 MSFS populations had greater GLC concentrations than the $\mathrm{C} 0$ population, but relative to the amount of GLC concentration in the biomass, these changes were small.

Sucrose (SUC): Sucrose, which is a soluble carbohydrate, had the lowest concentration in the C-1 population $\left(15.9 \mathrm{mg} \mathrm{g}^{-1}\right)$ and the highest concentration in the $\mathrm{C} 3$ and $\mathrm{C} 4$ populations $\left(20 \mathrm{mg} \mathrm{g}^{-1}\right)$. The variation among the $\mathrm{C} 5$ half-sib families was equivalent to the range between the $\mathrm{C} 0$ and the $\mathrm{C} 4$ population.

Soluble glucose (GLCS): Soluble glucose is the noncell-wall glucose in the biomass. There were no significant differences among the populations or half-sib families for GLCS, which had a mean of $4.3 \mathrm{mg} \mathrm{g}^{-1}$.

Fructose (FRU): There were significant differences for fructose, which is also a soluble carbohydrate, even though the concentration of fructose in the biomass was less than that of GLCS. Selection for decreased IVDMD resulted in decreased FRU, while selection for increased IVDMD resulted in increases in FRU concentration. After selection pressure for winter survival was applied, FRU concentration decreased. The range for FRU concentration between $\mathrm{C}-1$ and $\mathrm{C} 3$ was 1.9 to $3.8 \mathrm{mg} \mathrm{g}^{-1}$, respectively.

Rhamnose (RHA) and Fucose (FUC): Concentrations of RHA and FUC were very low, although there were significant differences among the C5 half-sib families for RHA but not for the populations. The FUC concentration of the C-1 was significantly larger than that of the other populations, but the difference was very small. The mean concentrations for RHA and FUC were 1.01 and $0.12 \mathrm{mg} \mathrm{g}^{-1}$, respectively. 
Uronic acids (UA): There were small differences among populations and C5 half-sib families for UA. The C3 population had a significantly greater UA concentration than the $\mathrm{C} 0$ and $\mathrm{C}-1$ populations (17.4 vs. $16.9 \mathrm{mg} \mathrm{g}^{-1}$ ).

p-Coumarate esters (PCA): There were significant difference among the population and the half-sib families, but there were no apparent trends associated with selection for IVDMD. The mean PCA concentration was $5.86 \mathrm{mg} \mathrm{g}^{-1}$.

Etherified ferulates (FETH): There were no significant differences among populations or C5 half-sib families. The mean FETH concentration was $0.45 \mathrm{mg} \mathrm{g}^{-1}$.

Esterified ferulates (FEST): There were significant differences among populations and C5 half-sib families for FEST. Selection for decreased IVDMD resulted in a decrease in FEST, and selection for increased IVDMD resulted in an increase in FEST concentration. The populations with the highest FEST were the $\mathrm{C} 1$ and the $\mathrm{C} 4$ populations. All the C5 half-sib families but one, 34106, had significantly higher FEST concentrations than the C0 population. The mean FEST concentrations for $\mathrm{C}-1$ and $\mathrm{C} 4$ were 1.42 and $1.79 \mathrm{mg} \mathrm{g}^{-1}$, respectively.

Ethanol (ETOH): ETOH is the ethanol yield produced from hexoses (predominately glucose from cellulose, but also cell wall galactose and mannose and soluble glucose, fructose, and the hydrolysis products of sucrose) following dilute acid pretreatment and simultaneous enzymatic scarification and fermentation (Vogel et al., 2011). Selection for decreased IVDMD resulted in decreased ETOH, while selection for high IVDMD resulted in populations with increased ETOH. After selection pressure was applied for winter hardiness in addition to IVDMD, ETOH declined in concentration. The mean ETOH concentrations for C-1 and C3 were 79.4 and $89.5 \mathrm{mg} \mathrm{g}^{-1}$, respectively.

\section{DISCUSSION}

At the time that this long-term selection study was initiated, it was known that switchgrass was a sexual, outcrossing polyploid and that IVDMD was a complex trait, so the feasibility of improving the IVDMD of switchgrass by breeding was uncertain. The initial divergent selection breeding work and associated grazing trial that resulted in the cultivar Trailblazer demonstrated the feasibility of breeding for increased or decreased IVDMD in switchgrass and the positive economic impact of improving digestibility (Casler and Vogel, 1999). The subsequent breeding work for increased IVDMD was conducted to determine the feasibility of making additional breeding gains in IVDMD. The subsequent two breeding generations resulted in additional increases in IVDMD but also resulted in the unexpected consequence of decreased winter survival of the C3 population as documented in previous reports and again in this study (Casler et al., 2002; Vogel et al., 2002). Biomass yield was also decreased (Casler et al., 2002; Vogel et al., 2002). The Trailblazer-based populations are the only populations in the ARS-Lincoln switchgrass breeding program in which breeding was conducted only for increased IVDMD. In all other populations in which breeding work was conducted for increased IVDMD, forage yield was used as an equally weighted co-selection factor by using a selection index, and there has not been any reduction in winter survival in any of those populations, including a 'Cavein-Rock' based population series that is now in C5. The C1 Cave-in-Rock population was released as the cultivar Shawnee, which has increased IVDMD in comparison with its parent population (Vogel et al., 1996).

The effects of using winter survival as a co-selection factor along with IVDMD in the C4 and C5 breeding cycles using the B\&WFS breeding system on biomass composition traits also were unexpected. Winter survival increased and IVDMD decreased, clearly showing an association between the two traits. The mechanism by which selection for IVDMD affected winter survival is unknown, but it may be associated with vascular structure. In the autumn of 1986 before a killing frost, senior author K. Vogel observed that leaves on plants in the original C4 RRPS selection nursery appeared to be more flaccid than leaves on plants in adjacent switchgrass selection nurseries. This was the nursery in which winter kill was first observed in this population. Anatomical analysis of a few specific high and low lignin plants from the C-1 and C3 populations demonstrated that there have been significant changes in the stem anatomy of the plants from the different breeding generations (Sarath et al., 2011). Plants with high lignin concentration from the $\mathrm{C}-1$ population had greater concentrations of cortical schlerenchyma and fibers around the vascular bundles than plants with reduced lignin concentration from C3. The anatomical data indicated that the extent of lignifications and tissue type had been altered by divergent selection for IVDMD. A possible explanation for the decrease in winter survival is that there is a collapse or partial collapse of some of the vascular tissue in the switchgrass plants with reduced IVDMD during the latter part of the growing season, reducing the potential translocation of carbohydrates essential for winter survival to the crown, roots, and rhizomes. Reduced turgor pressure due to the partial collapse of vascular tissue could explain the flaccid appearance of the leaves of the plants in the selection nursery in which extensive winter kill first occurred. Alternatively, the association of traits that led to increased IVDMD of the shoot system could have impaired important developmental aspects of the below-ground parts of the plants related to transition to dormancy and the acquisition of winter hardiness.

The divergent breeding for IVDMD resulted in significant changes in almost all plant biomass constituents, which was another unexpected result because the base population was an outcrossing octaploid, and only a small number of breeding generations were conducted. The number of potential loci that could be involved in the expression of all 
these traits for an octaploid is very large. The results clearly show that forage digestibility as measured by the IVDMD test is affected by many composition factors that can be genetically modified by selection for increased or decreased IVDMD in switchgrass. These changes were largely independent of plant maturity, which can affect biomass composition (Gabrielsen et al., 1990; Mitchell et al., 2001).

Selection for increased IVDMD resulted in reduced NDF, ADF, and ADL concentrations of the switchgrass biomass. Selection for reduced IVDMD had the opposite effect. The positive effects of the reduced level of these biomass fractions has long been known to be associated with improvements in forage digestibility by ruminants (Buxton et al., 1996; Smith et al., 1991). The NDF fraction obtained by the detergent fiber analyses method has often been assumed to represent the cell wall material of the biomass. In this study, it was possible to determine CWC by summation of the concentrations of the cell wall constitutions. There were significant differences for NDF concentration but not for CWC, and their correlation was relatively low $(r=0.45)$, indicating that they are not exactly the same biomass composition component. There were associated changes in NSC with selection for increased IVDMD, resulting in an increase in NSC and the opposite with selection for decreased IVDMD. The change in nonstructural carbohydrates is consistent with the known positive effects of increases in NSC on ruminant digestibility (Buxton et al., 1996). There were significant differences for all the cell wall constituents among the populations produced by the divergent selection for IVDMD except for FETH. Depending on the constituent, the concentrations either decreased or increased with each generation of selection for IVDMD. Selection for increased IVDMD also resulted in increases in FRU, SUC, and STA constituents of NSC. When winter survival was included as a selection criterion in C4 and C5, the changes were reversed for most cell wall and NSC constituents. These results demonstrate that divergent selection for increased IVDMD did not change total biomass $\mathrm{C}$ concentration but changed the distribution of $\mathrm{C}$ within the plant by changing biomass fiber and NSC concentrations and the concentrations of their constituents. These chemical changes are associated with the previously reported changes in the plant anatomy of specific plants (Sarath et al., 2011).

Genetic modification of plant biomass to improve its conversion to liquid fuels has received considerable research attention in recent years, and most of this research work has focused on modifying lignin concentrations and composition. A simple Google Scholar electronic reference search using the term "cell wall lignin" produced 19,000 results for the period 2008 to the present. In this study, the correlation between IVDMD and ETOH was $r=0.84(P<0.001)$, which indicates that the results from breeding for increased IVDMD are directly applicable to production of ethanol via SSF from biomass. This research indicates that in addition to lignin, many other cell wall and cell soluble constituents are factors in the breakdown of plant biomass by ruminants and the potential production of ethanol from biomass. Sarath et al. (2011) suggested that only about $50 \%$ of the variation in ethanol yield from specific plants selected from these populations could be explained by differences in lignin concentration. Acid detergent lignin was more responsive to divergent selection for IVDMD than was Klason lignin. It is beyond the scope of this report to address the relationships among the numerous plant biomass constituents that were analyzed and to determine which constituents had the most significant direct effects on both IVDMD and potential ethanol yield via SSF and fermentation.

The results of the C5 half-sib family analysis demonstrate that there is still a significant amount of genetic variation in the NE Trailblazer C5 population for most of the analyzed traits. Because the number of families is limited, there is potential for inbreeding depression to affect some of the traits if the breeding work is continued. It may be difficult to separate the effects of selection for IVDMD and inbreeding on biomass yields if the breeding work is continued with this population. The populations developed by this breeding work should be useful in molecular biology research on the genetic control of cell wall traits in polyploid grasses. The use of the MSFS method did not result in significant improvements in comparison with B\&WFS for the traits being selected, but it did result in small differences for some of the associated traits including NDF and SC.

The primary conclusions from this multigeneration study on modifying forage digestibility are that selection for the heritable complex trait IVDMD affected a large number of plant biomass characteristics including plant anatomy and the concentration of many biomass constituents and also adversely affected plant fitness. Co-selection for a fitness trait such as biomass yield should be practiced when breeding to modify plant biomass composition of perennial grasses such as switchgrass. Agricultural fitness of perennial grasses needs to be included as an evaluation factor when breeding to modify biomass composition for use by ruminants and biorefineries.

\section{References}

Anderson, B., J.K. Ward, K.P. Vogel, M.G. Ward, H.J. Gorz, and F.A. Haskins. 1988. Forage quality and performance of yearlings grazing switchgrass strains selected for differing digestibility. J. Anim. Sci. 66:2239-2244.

Buxton, D.R., D.R. Mertens, and D.S. Fisher. 1996. Forage quality and ruminant nutrition. In: L.E. Moser, D.R. Buxton, and M.D. Casler, editors, Cool-season forage grasses. Agronomy Monograph no. 34. ASA, CSSA, SSSA, Madison, WI. p. 229-266.

Casler, M.D., D.R. Buxton, and K.P. Vogel. 2002. Genetic modification of lignin concentration affects fitness of perennial herbaceous plants. Theor. Appl. Genet. 104:127-131. doi:10.1007/s001220200015 
Casler, M.D., R.B. Mitchell, and K.P. Vogel. 2012. Switchgrass. In: C. Kole, CP. Joshi, and D.R. Shonnard, editors, Handbook of Bioenergy Crop Plants. CRC Press, Taylor and Francis Group, Boca Rotan, FL. p. 563-590.

Casler, M.D., and K.P. Vogel. 1999. Accomplishments and impact from breeding for increased forage nutritional value. Crop Sci. 39:12-20. doi:10.2135/cropsci1999.0011183X003900010003x

Dien, B.S., H.G. Jung, K.P. Vogel, M.D. Casler, J.F.S. Lamb, P.J. Weimer, L. Iten, R.B. Mitchell, and G. Sarath. 2006. Chemical composition and response to dilute-acid pretreatment and enzymatic saccharification of alfalfa, reed canarygrass, and switchgrass. Biomass Bioenergy 30:880-891.

Gabrielsen, B.C., K.P. Vogel, B.E. Anderson, and J.K. Ward. 1990. Alkali-labile lignin phenolics and forage quality in three switchgrass strains selected for differing digestibility. Crop Sci. 30:1313-1320. doi:10.2135/cropsci1990.0011183X00300 $0060032 \mathrm{x}$

Hopkins, A.A., K.P. Vogel, and K.J. Moore. 1993. Predicted and realized gains from selection for in vitro dry matter digestibility and forage yield in switchgrass. Crop Sci. 33:253-258. doi:10.2135/cropsci1993.0011183X003300020007x

Moore, K.J., L.E. Moser, K.P. Vogel, S.S. Waller, B.E. Johnson, and J.F. Pedersen. 1991. Describing and quantifying growth stages of perennial forage grasses. Agron. J. 83:1073-1077. doi:10.2134/agronj1991.00021962008300060027x

Mitchell, R.B., J.O. Fritz, K.J. Moore, L.E. Moser, K.P. Vogel, and D.D. Redfearn. 2001. Predicting forage quality in switchgrass and big bluestem. Agron. J. 93:118-124. doi:10.2134/ agronj2001.931118x

Murray, I., and I. Cowe. 2004. Sample preparation. In: C.A. Roberts, J. Workman, Jr, and J.B. Reeves, III, editors, Near-infrared spectroscopy in agriculture. Agronomy Monograph no. 44. ASA, CSSA, and SSSA, Madison, WI. p. 75-112.

Newell, L.C., and W.J. Moline. 1978. Forage quality evaluation of twelve grasses in relation to season of grazing. Nebr. Res. Bull. 283.

Sarath, G., B. Dien, A. Saathoff, K.P. Vogel, R.B. Mitchell, and H. Chen. 2011. Ethanol yields and cell wall properties in divergently bred switchgrass genoytpes. Bioresour. Technol. 102:9579-9585. doi:10.1016/j.biortech.2011.07.086
SAS Institute. 2008. SAS version 9.2. SAS Institute Inc., Cary, NC. Shenk, J.S., and M.O. Westerhaus. 1991. Population definition, sample selection, and calibration procedures for near infrared reflectance spectroscopy. Crop Sci. 31:469-474. doi:10.2135/ cropsci1991.0011183X003100020049x

Smith, L.W., H.K. Goering, D.R. Waldo, and C.H. Gordon. 1991. In vitro digestion rate of forage cell wall components. J. Dairy Sci. 54: 71-76.

Tilley, J.A., and R.A. Terry. 1963. A two-stage technique for the in vitro digestion of forage crops. J. Br. Grassl. Soc. 18:104111. doi:10.1111/j.1365-2494.1963.tb00335.x

Vogel, K.P. 2004. Switchgrass. In: L.E. Moser, L. Sollenberger, and B. Burson, editors, Warm-season $\left(\mathrm{C}_{4}\right)$ grasses. ASACSSA-SSSA Monograph. Madison, WI. p. 561-588.

Vogel, K.P., B. Dien, H. Jung, M. Casler, S. Masterson, and R.B. Mitchell. 2010. Quantifying Actual and Theoretical Ethanol Yields for Switchgrass Strains Using NIRS Analyses. BioEnergy Res.:1-15.

Vogel, K.P., F.A. Haskins, H.J. Gorz, B.A. Anderson, and J.K. Ward. 1991. Registration of 'Trailblazer' switchgrass. Crop Sci. 31:1388. doi:10.2135/cropsci1991.0011183X003100050080x

Vogel, K.P., A.A. Hopkins, K.J. Moore, K.D. Johnson, and I.T. Carlson. 1996. Registration of 'Shawnee' switchgrass. Crop Sci. 36:1713. doi:10.2135/cropsci1996.0011183X003600060051x

Vogel, K.P., A.A. Hopkins, K.J. Moore, K.D. Johnson, and I.T. Carlson. 2002. Winter survival in switchgrass populations bred for high IVDMD. Crop Sci. 42:1857-1862. doi:10.2135/ cropsci2002.1857

Vogel, K.P., H.J. Gorz, and F.A. Haskins. 1981. Divergent selection for in vitro dry matter digestibility in switchgrass. Crop Sci. 21:39-41. doi:10.2135/cropsci1981.0011183X002100010011x

Vogel, K.P., and J.F. Pedersen. 1993. Breeding systems for crosspollinated perennial grasses. Plant Breed. Rev. 11:251-274.

Vogel, K.P., J.F. Pedersen, S.D. Masterson, and J.J. Toy. 1999. Evaluation of a filter bag system for NDF, ADF, and IVDMD forage analysis. Crop Sci. 39:276-279. doi:10.2135/cropsci199 9.0011183X003900010042x

Vogel, K.P., G. Sarath, A.J. Saathoff, and R.B. Mitchell. 2011. Switchgrass. In: N.G. Halford and A. Karp, editors, Energy crops. The Royal Soc. Chem., Cambridge, UK. p. 341-380. 